\title{
Learning to Teach ESP: Case Studies of Two Vietnamese General English Teachers
}

\author{
Le Thi Hong Duyen \\ Haiphong University of Medicine and Pharmacy, Haiphong City, Vietnam
}

\begin{abstract}
Given increasing concern about teaching quality, more and more attention has been paid to the issue of teacher professional development. While there is a myriad of research on English language teaching (ELT) teacher professional development, little has been done on the same issue for English for Specific Purposes (ESP) teachers. In Vietnam, most teachers of English in non-Englishmajor universities or vocational colleges have to teach ESP courses while their backgrounds are unrelated to the disciplines they are asked to teach. Based on this fact, this study was designed to investigate how general English teachers learn to teach ESP through the cases of two teachers of English at a medical university. Semistructured interviews, classroom observations, and postobservation interviews were used to explore the challenges of those teachers in dealing with new subject matter and seeking appropriate solutions. Also, implications for ESP teacher professional development in Vietnam are drawn.
\end{abstract}

It is true that with the reconceptualization in teaching and learning over the past 50 years, research into teacher professional development has made significant changes (Schnellert, Butler, \& Higginson, 2008). However, while research on English language teaching (ELT) teacher professional development seems to blossom, little has been done on the same issue for English for Specific Purposes (ESP) teachers. This problem was once voiced by Chen (2000):

In recent years, although ESP has been a popular catchphrase in the field of language learning and teaching, in light of the thin to non-existent provision of ESP teacher education, training programs and supervision in many areas of the world, the demand for ESP courses has gone largely unanswered. (p. 389)

In Vietnam, ESP teaching is still in its infancy. Most teachers of English who work in nonEnglish-major universities or vocational colleges have to take charge of at least one ESP course as a common requirement of the Ministry of Education and Training (MoET), yet they are not trained to teach English of the disciplines that they are asked to undertake. The situation urges the researcher to study the ways those teachers try to survive as "reluctant dwellers in a strange and uncharted land" (Hutchinson \& Waters, 1987, p. 158), or simply put, the ways they learn to teach ESP.

In this study, the researcher does not intend to cover all ESP realms but focuses on case studies of two Vietnamese teachers of general English (GE) in a medical university. The scope of the

Language Education in Asia, 2014, 5(2), 228-237. http://dx.doi.org/10.5746/LEiA/14/V5/I2/A05/Duyen 
study is not for generalization but allows the researcher to look deep inside the cases to see what is really happening.

\section{Literature Review}

\section{ESP Teachers' Required Knowledge Base and Needed Competencies}

According to Tom and Valli (1990), the term knowledge base refers to the repertoire of knowledge, skills, and dispositions that teachers need to effectively carry out classroom practices. Furthermore, Shulman (1986) proposed seven categories of teachers' knowledge, specifically, (1) content knowledge, (2) general pedagogical knowledge, (3) curriculum knowledge, (4) pedagogical content knowledge, (5) knowledge of learners and their characteristics, (6) knowledge of educational contexts, and (7) knowledge of educational ends, purposes, and values. These constructs of knowledge illustrate the complex nature of the teacher knowledge base.

Hutchinson and Waters (1987) claimed that ESP teachers should have the same qualities as general English teachers. Similarly, Sadeghi (cited in Maleki, 2008, p. 9) proposed the qualifications of ESP teachers, including English language knowledge, thorough command of the course design, and expert knowledge of the related field. Additionally, the knowledge of "needs analysis, syllabus design, material writing or adaptation and evaluation" (Venkatraman \& Prema, 2007, p. 1) and the understanding of typical genres featured in the disciplines (Hüttner, Smit, \& Mehlmauer-Larcher, 2009) are also important for ESP teachers in order to satisfy the changing needs of ESP courses.

In terms of ESP teachers' knowledge of subject matter, Hutchinson and Waters (1987) stated that ESP teachers "have to struggle to master language and subject matter beyond the bounds of their previous experience" (p. 60). However, they also contend that ESP teachers require three things only: (1) a positive attitude towards the ESP content, (2) a knowledge of the fundamental principles of the subject area, and (3) an awareness of how much they probably already know (p. 163).

With regards to competencies that ESP teachers need to acquire if they want to succeed in ESP courses, Venkatraman and Prema $(2007,2013)$ have developed and validated a useful set of 65 necessary competencies for teachers of English in the engineering colleges in India. Those competencies are grouped under two main parts, namely, "General Competencies," comprising 17 items and "Subject-Specific Competencies," containing 48 statements related to different skills and grammar domains. By building such a set of competencies, the authors aimed at pointing out the training needs of the teachers of English in the engineering field and providing a framework for conducting both in-service and pre-service training programs for aspiring teachers of English for science and technology (EST). Although the list of competencies was developed particularly for EST teachers, it is believed to inspire researchers and teachers of other fields to establish their own ones so as to identify practical needs for ESP teacher training according to a competence-based approach.

\section{ESP Teachers' Roles}

In order to emphasize the fact that the ESP profession covers many more responsibilities than teaching, Dudley-Evans and St. John (1998) call teachers of this field "ESP practitioners" (p. 13) and have devised five critical roles they should play as (1) a teacher, (2) a course designer and materials provider, (3) a collaborator, (4) a researcher, and (5) an evaluator. According to the authors, as in the role of a teacher, an ESP practitioner is recommended to "draw on students' knowledge of the content in order to generate genuine communication in the classroom" (p. 
13) and to negotiate with the students the suitable ways to reach lesson goals, as well as to be flexible and willing to take risks. Specifically, ESP teachers in many cases have to be not only the course designer but also provide materials by selecting, adapting, and even writing materials to suit the learners' needs. By the role of a collaborator, the authors elaborate that ESP practitioners should be interested in working with content departments, subject matter teachers, and specialists of the field in order to engage with the disciplines they need to focus on. The fourth role, researcher, refers to the ability to carry out studies on learners' needs, target situation analysis, and genre analysis, or the discourse of the text types that are related to the discipline. Another important role, that of an evaluator, is also mentioned, referring to the testing of students and the evaluation of the courses and teaching materials (p. 16).

\section{Research on ESP Teacher Training}

The lack of ESP teacher training courses has been reported in a number of articles in the literature. For example, Chen (2000) from Taiwan claimed that "the ESP profession faces twin problems, namely lack of teacher training programs in many areas of the world and the dissatisfaction with conventional theory-into-practice training models" (p. 389).

With the limitation of training, ESP teachers have been recommended to undertake self-training and self-reflection as temporary but helpful solutions. For instance, Master (1997) encouraged ESP practitioners to apply the self-training approach through a process of professional reflection, problem solving, and decision making, so as to cope with the challenges arising during their practice of ESP. Similarly, Chen (2000) conducted a study on self-training for ESP through action research, in which a GE teacher acquired and developed ESP expertise by reflecting on her own teaching tasks, hence improving performance in the classroom. The researcher added that this "is not a substitute for conventional training entirely: not the life boat itself, but rather a life belt" (p. 389). Also in terms of self-reflection, Wu and Badger (2009) conducted a case study with three teachers of maritime English in China to find out the strategies of those teachers in response to unpredicted problems in subject knowledge during their classes, the situation called "In-class Subject-Knowledge Dilemma" or ISKD (p. 19). In another study, Ghanbari and Rasekh (2012) examined the experiences and strategic behavior of two ESP professionals in Iran with the belief that new ESP teachers can learn precious lessons from those veteran ESP practitioners through their thorny journey of professionalization.

Although the issue of how GE teachers learn to teach ESP has started to gain attention from researchers worldwide, in Vietnam, such type of research seems to be absent, leaving a big gap for the topic of ESP teacher training in its context.

\section{Objectives and Goals}

\section{The Present Study}

This study is designed to investigate the ways two new teachers of ESP at a medical university learn to adapt themselves in a new teaching environment that they have never experienced before. At the same time, some challenges and possible solutions used by these two teachers during their journeys of learning to teach ESP are explored. With these aims in mind, the researcher has tried to answer the following research questions:

1. How do the two GE teachers evaluate their competencies and their roles as ESP teachers?

2. In what ways do those teachers learn to teach medical English?

3. What are their challenges, their respective solutions, and their expectations in teaching medical English? 


\section{The Setting}

The study was conducted in a typical context of teaching ESP in a medical university in Vietnam. According to the regulations from MoET, students at non-English-major universities have to study a semester of ESP after they finish two terms of English for General Purposes (EGP). Therefore, GE teachers at those universities normally take charge of at least one or more ESP courses depending on the subdivisions within each discipline.

\section{The Participants}

As mentioned previously, the participants are two new teachers of ESP in a medical university in Vietnam. In order to guarantee their confidentiality, their real names were not used, and they were labeled as T1 and T2 hereinafter. They are both in their early thirties, one having 3 years and the other 1 year of experience in teaching medical English.

\section{Methods and Procedures}

Within the research design of a case study, the researcher took advantage of semistructured interviews and natural observation of teaching practices via video recording and postobservation interviews so as to meet the purpose of the study's research questions. The study was conducted within the 4 months of a medical English course. The first semistructured interviews were delivered 2 weeks after the beginning of the course. Each teacher was observed three different times with the observation interval of at least 2 weeks. After that, the researcher took notes from the observation and conducted the post-observation interviews to investigate the problems and issues arising from their ESP practice as well as to triangulate with the data collected from the first interviews.

\section{Findings of the Study \\ Research Question 1: Self-Evaluation of Needed Competencies and Roles of ESP Teachers}

Needed competencies. In the initial interviews, the teachers were asked to express their thoughts about the competencies needed to teach ESP. With some hesitation, they gave quite similar answers that they firstly needed to have qualities and competencies of a teacher of GE, and then they also had to equip themselves with as much knowledge of the subject matter as possible. However, neither of them could define the competencies in detail.

In evaluating their own competencies to teach the ESP course at their university, they both reported that they could meet the requirements of the course; but they also admitted their weakness and lack of medical knowledge, which was their big concern. For example, T2 said:

I think I can teach the course at basic requirement but to be honest, I am not satisfied with myself, yes, my knowledge of specific medical disciplines is not enough. (T2, Interview 1)

Roles of ESP teachers. While sharing the ideas about the roles of ESP teachers, both teachers emphasized the word orientation, with the explanation that ESP teachers should be the ones who lead students into the subject, in this case, medical English.

After that, the participant teachers were asked to show their agreement or disagreement on the roles proposed by Dudley-Evans and St. John (1998) as well as to evaluate their respective roles by grading on a scale from zero to ten. Interestingly, they both agreed with all the roles mentioned, though they could not articulate the specific roles in their own words. The results, shown in Table 1, reveal that not any role was rated under the average score of five, which also 
corresponds to their self-evaluation of competencies needed.

Table 1

Teachers' Self-Evaluation of ESP Teachers' Roles

\begin{tabular}{|c|c|c|c|c|}
\hline \multirow{2}{*}{$\begin{array}{l}\text { Roles of } \\
\text { ESP } \\
\text { practitioners }\end{array}$} & \multicolumn{2}{|r|}{$\mathrm{T} 1$} & \multicolumn{2}{|r|}{$\mathrm{T} 2$} \\
\hline & Grade & Explanation & Grade & Explanation \\
\hline Teacher & 8 & $\begin{array}{l}\text { "I think I can do a good job } \\
\text { as a teacher." }\end{array}$ & 8 & $\begin{array}{l}\text { "I am confident to be a } \\
\text { teacher of English." }\end{array}$ \\
\hline $\begin{array}{l}\text { Course } \\
\text { designer } \\
\text { and } \\
\text { materials } \\
\text { provider }\end{array}$ & 8 & $\begin{array}{l}\text { "I am one of the persons in } \\
\text { the department to prepare } \\
\text { for the course design and } \\
\text { materials providing." }\end{array}$ & 6 & $\begin{array}{l}\text { "I am not the person in } \\
\text { charge of course design, but } \\
\text { I often prepare my own extra } \\
\text { materials for my lessons." }\end{array}$ \\
\hline Researcher & 6 & $\begin{array}{l}\text { "Honestly, I don't think I do } \\
\text { research on the subject } \\
\text { frequently." }\end{array}$ & 5 & $\begin{array}{l}\text { "I think any ESP teacher } \\
\text { should study more and } \\
\text { deeply into the subject } \\
\text { matter, I am a novice } \\
\text { teacher so my research skill } \\
\text { is still limited." }\end{array}$ \\
\hline Collaborator & 5 & $\begin{array}{l}\text { "I still haven't had many } \\
\text { chances to connect with } \\
\text { teachers from other } \\
\text { departments as well as } \\
\text { students." }\end{array}$ & 7 & $\begin{array}{l}\text { "During my teaching, I often } \\
\text { collaborate with students } \\
\text { and sometimes help other } \\
\text { teachers with some } \\
\text { translation documents." }\end{array}$ \\
\hline Evaluator & 5 & $\begin{array}{l}\text { "I do not evaluate the course } \\
\text { on regular basis, we only } \\
\text { base on the results of the } \\
\text { final written exam. It's not } \\
\text { really an evaluation, I think." }\end{array}$ & 6 & $\begin{array}{l}\text { "I am not sure that I do this } \\
\text { role well because of our poor } \\
\text { testing system." }\end{array}$ \\
\hline
\end{tabular}

\section{Research Question 2: Ways of Learning to Teach ESP}

Self-studying. Both teachers had quite similar educational backgrounds: they both achieved a master's degree in teaching English as a foreign language at one of the most prestigious universities in Vietnam. However, they both claimed that they only learnt from the MA course a few basic theories about ESP, which seemed to be vague and unhelpful. Therefore, when they were assigned to teach ESP, the first thing they did was self-studying. They spent a great deal of time studying the textbook, looking up the medical terminology in a dictionary, and searching for medical topics on the Internet. For example, T2 reported having to study the lessons in the textbook deeply, and often searched journals or information from Google for difficult medical terms. Also, T1 took it for granted that:

before any course, you have to prepare the lessons, for ESP course, the terminology is very difficult, so you have to study it first. ... We [the teachers of ESP] have to study by ourselves as a learner of a new subject. (T1, Interview 1)

Learning from colleagues. Apart from self-study, the teachers also learned from their colleagues, especially the experienced ones. In fact, they had to observe all kinds of classes in their teaching probation time. During that time, they both studied on their own and observed classes taught by their colleagues. In that way, they knew how to deliver the lessons and also learned new terminologies and content from medical English that were quite new to them. 
Besides learning through the observation of the colleagues in their department, the teachers also found chances to consult with colleagues from other departments who were teachers of the subject matter. However, they did it only rarely because of a weak connection between ESP teachers and teachers of the subject matter:

When I found any difficult concept in medicine, I first look it up in the internet or ask my students, I only ask other teachers of medicine in case I am still confused . . . but actually, I'm afraid to ask them such issues, you know, they are very busy. (T2, Interview 1$)$

By and large, the communication between ESP teachers and the subject teachers was not very close and systematic, as both teachers confessed.

Learning from students. From the interviews and the natural class observation, there were many times the two teachers had to ask students to help them explain some medical knowledge that they were not very clear about.

Well, I think they [the students] are eager to help me and when being asked about medical knowledge, they seem to be more engaged in the lesson. So it is very useful and very interesting to consult with students the things that you do not know. (T1, Interview 1)

However, things did not always go smoothly. Sometimes the teachers had to cope with the problem that the students gave different answers and they argued with one another. In such situations, the teachers noted that:

I ask students to check the issue later and give me the correct answer in the next class. At the same time, I note down the issue and find the explanation later. (T2, Interview 2)

I was really confused in such situation. I myself do not know who is correct or not because my knowledge of medicine is limited. And you know, the students of the third year do not have a thorough knowledge of medical issues too. It's understandable. (T1, Interview 2)

It was quite obvious that in learning to teach ESP, the teachers had to struggle with a lot of difficulties which were both objective and subjective.

\section{Research Question 3: Challenges in Teaching ESP, Solutions, and Expectations}

Objective challenges. In reflecting on the objective challenges they had in teaching ESP, the teachers showed their dissatisfaction with the current textbooks for the course, which were very out-of-date and unattractive to learners. In addition, the structures of many ESP coursebooks were nearly the same in the way they only focused on the texts, terminologies, reading comprehension, and translation, which might hinder the creativeness of the teachers and motivation of the students.

Another objective challenge was concerned with the students' demotivation and low level of English competence. In Vietnam, in most non-English-major universities, a large portion of students only study English in general and ESP in particular as a compulsory subject. They do not have clear learning objectives and interest for the subject. Such common types of challenges in teaching ESP in the Vietnamese context were also voiced by the two participants 
of this study.

One of my difficulties in teaching ESP is the mixed English levels of students of the same class. There are some students who are quite good at English, they show great interest to the lessons. However, there still remain a large number of students who do not show positive attitudes towards learning ESP because of their limited ability in acquiring difficult terminologies in the coursebook. . . I I feel that they just study for passing the final exam, not for their real needs. (T1, Interview 1)

In addition to the two main challenges mentioned, some other difficulties, such as large-sized classes, limited time frame for the course, limited access to practice, and matters of course evaluation were also complained about by the teachers.

Subjective challenges. The main subjective challenges were found in the teachers themselves. They both confessed that they had limited knowledge of medicine, which caused them a lot of embarrassment in some cases. Moreover, in order to prepare for a lesson of medical English, the teachers had to spend a lot of time and effort in searching the Internet, looking up terminologies in specific dictionaries, or asking other colleagues for help. Consequently, it made them much more tired than preparing a normal lesson of GE would have.

For the first time when I was delegated to teach the course, I was very eager to study new things, and then I found that it was really time-consuming and tiring. Then, after a long time, I find that I have lost my patience to study deeply into the subject matter, the fact is that I only focus on the things in the text book and deliver the lessons as normal routine. (T2, Interview 1)

Solutions and expectations. Firstly, regarding the out-of-date coursebooks, the teachers reported that they had prepared extra materials to supplement the lessons, but it was revealed from the classroom observations that both teachers had few chances to use such prepared materials. In the post-observation interviews, the participants blamed the lack of taking advantage of extra materials on the previously mentioned lack of time. Therefore, they expected to have had more time allocated for ESP classes.

Also, they would like to work with other colleagues in the department to compile a more practical syllabus. However, this is a long-term project. At the moment, the only temporary solution is that the teachers have to find the extra materials themselves to make lessons less boring and more effective (as mentioned by T2 in Interview 2). T1 remarked:

I think in order to build up an appropriate syllabus for the course, it requires a lot of time and effort. It cannot be done overnight. And you know, we [the teachers at the department] are not really equipped fully with the necessary skills for course design and materials development. We really need help from other experts or organization. Well, it's really difficult anyway. (T1, Interview 2)

Secondly, for the problem of students' demotivation, during the class observations of the two teachers, it was recorded that in order to attract students to their lessons, the teachers also created more communicative activities such as role-play and problem solving as if they were in real-life working situations. However, not all students could follow the activities because of their mixed level of English competencies. Another problem was again the limited class time. The teachers had to accomplish the lessons of the current coursebook within certain periods. 
Such a time issue was beyond their power to change. Therefore, in the final interviews, they expressed the wish to group students into different levels so that they could use appropriate activities as well as extra materials.

T1 proposed an idea of dividing the ESP course into two stages, in which the first stage would be compulsory for all students and the second stage optional. The first stage would be conducted like an introductory course to medical English; while in the second stage, based on students' needs, they would have a chance to study deeply what they really wanted for their future jobs. This solution was believed to be more effective because it would meet the demand of both low-level and high-level students.

For subjective challenges, the two teachers reported that they would still keep studying on their own and seek help from students and other colleagues so as to fill the gaps in their knowledge of subject matter while waiting for any formal ESP teacher training courses. They also realized that these temporary solutions sometimes made them feel tired and discouraged and that they had no other choices. Moreover, as the learning was spontaneous, the teachers were confused about their own career path and had no clear plans for their professional development, as reflected in T2's comments:

I really want to do something for my own professional development but I don't have any plans at the moment and to be honest, I don't know where to start. . . . I wish we can be trained formally to be real ESP teachers. (T2, Interview 2)

\section{Discussion and Implications for ESP Teacher Professional Development in Vietnam}

Based on the findings of the study, three main points are discussed and some implications and recommendations are drawn for the work of professional development of ESP teachers accordingly.

Firstly, the confusing identification of ESP teachers' roles and needed competencies seen in the two participant teachers reflects the understandable fact that they are not fully trained in knowledge of ESP-related issues. The findings of this study echo the implications of a previous study of a research group in Vietnam that the failure in an ESP program in a university in Vietnam could be attributed to lack of ESP teacher training programs and inappropriate materials (Duong, Bui, \& Bui, 2005). Obviously, if teachers cannot clearly articulate and understand what roles they have to do with their jobs and the skills required, they cannot be successful. It is recommended that in-service ESP training courses should be held nationwide so as to equip teachers with necessary knowledge of ESP, as well as to give them chances to raise their awareness of their own roles and for them to not only survive but to thrive in their career. Furthermore, in the long run, a framework of ESP teachers' required competencies for different disciplines, such as the one proposed by Venkatraman and Prema (2007), should be established in order to provide systematic guidelines for ESP teachers in the country.

Secondly, it can be seen from this study that there are still some existing problems in the ways the teachers learn to teach ESP. Although self-study is good, the teachers still lack self-reflection on their own practice, which is also very important. This explains why no clear strategies or stronger actions in response to the arising challenges were recorded in their reported statements, as well as in real class observations, compared to what has been observed in previous studies in other countries. Hence, self-reflection should be included in the contents of ESP teacher training courses. Also, networking and forums are good ways for teachers of the same disciplines to exchange and reflect on their own instructional practice of ESP. Via such channels, teachers will find more opportunities to engage more in ESP professional 
development activities.

Another problem is that the collaboration between the ESP teachers in this study with content departments and subject matter teachers is still weak. Therefore, it requires facilitation from the institutional level to strengthen the relationship by offering strategic plans and encouraging both ESP teachers and content teachers to work for the improvement of the ESP courses.

Additionally, in the ESP training courses, teachers should be instructed in how to benefit from such cooperation.

Finally, the findings on the teachers' solutions to challenges they coped with in their ESP teaching show some conflict between what they intended to do and the reality. For instance, in order to supplement the outdated coursebooks, extra materials were prepared, but the rigid and limited time frame prevented those materials from being applied in the lessons. Furthermore, the initiative of using real-life activities to motivate students was not always successful due to the mixed levels of students and large-sized classes. If such conflicts are not taken into serious consideration to reach harmonized solutions, the teachers will find themselves falling back into the old path of stagnant, let-it-be situations. Thus, while building ESP teacher training courses, such barriers cannot be ignored.

\section{Conclusion}

In short, during the journey of learning to teach ESP, the teachers encountered a lot of challenges which brought them to the situation of sink or swim. If the situation continues, that is to say, there are no training courses, no update of the coursebooks, or no proposed activities for their professional development to make them engaged in the courses and in the tasks of an ESP practitioner, it is likely that the teachers will find themselves becoming passive and demotivated, then gradually falling into boring routines.

Compared to the current extensive investment of MoET into the National Foreign Language 2020 Project, which aims at improving foreign language proficiencies of teachers and students in Vietnam, sadly, not any strategic plans are voiced for the ESP field. As long as ESP teacher training and education is still marginalized, the future of ESP and the decreasing quality of teaching it in Vietnam is foreseeable and predictable.

Although the present study was conducted with only two teachers and in short periods of time, which makes generalization impossible, it can be considered as a modest effort in investigating how GE teachers learn to teach ESP in a university context in Vietnam. In addition, it also raises the necessity of ESP teacher training in Vietnam. More importantly, it provides some recommendations for ESP teacher professional development as well as rings the warning bell about the status quo of ESP teaching in Vietnam. For a newly emerged environment of ESP, as in Vietnam, such research topics should be encouraged to develop the country's own model of ESP teacher training which will be very meaningful to the improvement of ESP teaching there.

\section{Author Note}

Le Thi Hong Duyen, Foreign Language Department, Haiphong University of Medicine and Pharmacy, Haiphong City, Vietnam.

Correspondence concerning this article should be addressed to Le Thi Hong Duyen, Foreign Language Department, Haiphong University of Medicine and Pharmacy, 72A Nguyen Binh Khiem Street, Ngo Quyen District, Haiphong, Vietnam. E-mail: hongduyen.yhp@gmail.com 


\section{References}

Chen, T.-Y. (2000). Self-training for ESP through action research. English for Specific Purposes, 19(4), 389-402. http://dx.doi.org/10.1016/S0889-4906(00)00008-9

Dudley-Evans, T., \& St. John, M. J. (1998). Developments in English for specific purposes: $A$ multi-disciplinary approach. Cambridge, England: Cambridge University Press.

Duong, T. P. O., Bui, M. C., \& Bui, L. C. (2005). Failure in an ESP program: Why? KOTESOL Proceedings 2005, 261-266.

Ghanbari, B., \& Rasekh, A. E. (2012). ESP practitioner professionalization through apprenticeship of practice: The case of two Iranian ESP practitioners. English Language Teaching, 5(2), 112-122. http://dx.doi.org/10.5539/elt.v5n2p112

Hutchinson, T., \& Waters, A. (1987). English for specific purposes: A learning-centred approach. Cambridge, England: Cambridge University Press. Available at http://dx.doi.org/10.1017/CBO9780511733031

Hüttner, J., Smit, U., \& Mehlmauer-Larcher, B. (2009), ESP teacher education at the interface of theory and practice: Introducing a model of mediated corpus-based genre analysis. System, 3オ1), 99-109. http://dx.doi.org/10.1016/j.system.2008.06.003

Maleki, A. (2008). ESP teaching: A matter of controversy. ESP World, 1(17)(7). Retrieved from http://www.esp-world.info/Articles_17/PDF/ESP\%20Teaching\%20Iran.pdf

Master, P. (1997). ESP teacher education in the USA. In R. Howard \& G. Brown (Eds.), Teacher education for $\angle S P$ (pp. 22-40). Clevedon, England: Multilingual Matters.

Schnellert, L. M., Butler, D. L., \& Higginson, S. K. (2008). Co-constructors of data, coconstructors of meaning: Teacher professional development in an age of accountability. Teaching and Teacher Education, 24(3), 725-750. http://dx.doi.org/10.1016/j.tate.2007.04.001

Shulman, L. S. (1986). Those who understand: Knowledge growth in teaching. Educational Researcher, 15(2), 4-14. http://dx.doi.org/10.3102/0013189X015002004

Tom, A., \& Valli, L. (1990). Professional knowledge for teachers. In W. R. Houston, M. Haberman \& J. Sikula (Eds.), Handbook of research on teacher education (1 st ed.) (pp. 373-392). New York, NY: Macmillan.

Venkatraman, G., \& Prema, P. (2007). Developing a set of competencies for teachers of English in engineering colleges. ESP World, 1(14)(6). Retrieved from http://www.esp-world.info/ Articles_14/India.htm

Venkatraman, G., \& Prema, P. (2013). Identification and validation of ESP teacher competencies: a research design. English Language Teaching, 6(2), 27-31.

Wu, H. D., \& Badger, R. G. (2009). In a strange and uncharted land: ESP teachers' strategies for dealing with unpredicted problems in subject knowledge during class. Eng/ish for Specific Purposes, 28(1), 19-32. http://dx.doi.org/10.1016/j.esp.2008.09.003 